\title{
IMPLEMENTASI STRATEGI PENGUJIAN KENDARAAN BERMOTOR
}

\section{IMPLEMENTING STRATEGY OF MOTOR VEHICLE TESTING}

\author{
Refita Syafitri ${ }^{1 *}$, Ike Rachmawati², Dine Meigawati ${ }^{3}$ \\ 1,2,3Program Studi Administrasi Publik, Fakultas Ilmu Administrasi dan Humaniora, \\ Universitas Muhammadiyah Sukabumi, Jl. R. Syamsudin, SH No. 50, Cikole, Kota Sukabumi \\ 43113
}

*Korespondensi: Refita Syafitri. Email: refitas31@gmail.com

(Diterima: 11-08-2020; Ditelaah: 15-08-2020; Disetujui: 18-08-2020)

\begin{abstract}
The purpose of this research is to describe the strategy implementation of motor vehicle testing conducted by the Local Technical Implementation Unit for Motor Vehicle Testing of the Local Office of Transportation of Sukabumi City. Method of this research is a qualitative approach by describing the strategy implementation of motor vehicle testing. Techniques for collecting data use interview, observation and documentation related to the focus of this research. Data of this research are qualitatively described. Based on results of this description, this research concludes three findings concerning the strategy implementation of motor vehicle testing conducted by the Local Technical Implementation Unit for Motor Vehicle Testing of the Local Office of Transportation of Sukabumi City. Firstly, the goal of motor vehicle testing has been generally perceived as good enough, although it is still found that most of motor vehicle owners do not know the importance and goal of motor vehicle testing. Secondly, the policy concerning motor vehicle testing is not massively socialized yet, and the control to the motor vehicle owners is still weak. Thirdly, the plan formulated to increase the public awareness through the non-cash payment of retribution is still hampered by the lack of public awareness that most of motor vehicle owners do not have the authomatic teller machine card of bank to pay the non-cash retribution.
\end{abstract}

Key words: Strategy Implementation, Local Own-Source Revenue, Motor Vehicle Testing.

\begin{abstract}
ABSTRAK
Tujuan penelitian ini adalah untuk mengetahui implementasi strategi pengujian kendaraan bermotor yang dilakukan oleh Unit Pelaksana Teknis Daerah Pengujian Kendaraan Bermotor Dinas Perhubungan Kota Sukabumi. Metode yang digunakan dalam penelitian ini adalah pendekatan kualitatif dimana penelitian ini bersifat deskriptif untuk menggambarkan implementasi strategi pengujian kendaraan bermotor. Teknik pengumpulan data menggunakan teknik wawancara, observasi dan dokumentasi terkait fokus penelitian. Data dalam penelitian ini dianalisis secara kualitatif. Penelitian ini menyimpulkan tiga hal terkait implementasi strategi pengujian kendaraan bermotor oleh Unit Pelaksana Teknis Daerah Pengujian Kendaraan Bermotor Dinas Perhubungan Kota Sukabumi. Pertama, sasaran dalam pengujian kendaraan bermotor secara umum sudah dikatakan cukup baik, namun masih terdapat hambatan, yaitu sebagian besar pemilik kendaraan tidak mengetahui manfaat dan tujuan dalam melaksanakan pengujian kendaraan bermotor. Kedua, kebijakan terkait pengujian kendaraan bermotor belum disosialisasikan secara massif dan masih lemahnya pengawasan kepada pemilik kendaraan yang menghilangkan buku uji. Ketiga, rencana yang sudah dibuat untuk meningkatkan kesadaran masyarakat melalui pembayaran retribusi secara nontunai masih terhambat pada kurangnya kesadaran masyarakat, yaitu sebagian besar pemilik kendaraan belum memiliki kartu anjungan tunai mandiri bank untuk melakukan pembayaran pengujian kendaraan bermotor secara nontunai.
\end{abstract}

Kata kunci: Implementasi Strategi, Pendapatan Asli Daerah, Pengujian Kendaraan Bermotor.

Syafitri, Refita; Rachmawati, Ike \& Meigawati, Dine. (2021). Implementasi Strategi Pengujian Kendaraan Bermotor. Jurnal GOVERNANSI, 7(1): 69-79. 


\section{PENDAHULUAN}

Pengujian kendaraan bermotor di Kota Sukabumi merupakan wewenang Dinas Perhubungan Kota Sukabumi sebagaimana diatur dalam Peraturan Walikota Nomor 1 Tahun 2013 tentang Unit Pelaksana Teknis Pengujian Kendaraan Bermotor. Pengujian kendaraan bermotor adalah serangkaian kegiatan menguji dan memeriksa bagian-bagian kendaraan bermotor, kereta gandengan, kereta tempelan dan kendaraan khusus dalam rangka pemenuhan terhadap persyaratan teknis dan laik jalan.

Pengujian kendaraan bermotor dilaksanakan oleh UPTD PKB Kota Sukabumi. Pemeriksaan dilakukan oleh penguji yang memenuhi persyaratan yang ditetapkan oleh pemerintah. Bagi kendaraan yang memenuhi kelaikan/lulus uji disahkan oleh pejabat yang ditunjuk dan diberi tanda uji, yaitu buku uji, plat uji, dan tanda samping. Dalam Peraturan Walikota Nomor 1 Tahun 2013 tentang Unit Pelaksana Teknis Pengujian Kendaraan Bermotor diatur bahwa pelaksanaan pengujian kendaraan bermotor meliputi pertama/mutasi masuk, pengujian berkala, numpang uji, penilaian kondisi teknis, dan penggantian buku uji yang rusak atau hilang. Tabel 1 menunjukkan data jumlah kendaraan yang diuji UPTD PKB Kota Sukabumi tahun 2018-2019.

Tabel 1. Data Jumlah Kendaraan yang Diuji UPTD PKB Kota Sukabumi Tahun 2018-2019

\begin{tabular}{llrr}
\hline \multirow{2}{*}{ No. } & \multirow{2}{*}{ Jenis Kendaraan } & \multicolumn{2}{c}{ Jumlah } \\
\cline { 2 - 4 } & & 2.018 & 2.019 \\
\hline 1 & Berkala Angkot & 885 & 757 \\
\hline 2 & Berkala & 4.947 & 4.898 \\
\hline 3 & Numpang Uji Masuk & 348 & 166 \\
\hline 4 & Petama Uji & 372 & 301 \\
\hline 5 & Mutasi Masuk & 99 & 66 \\
\hline Jumlah kendaraan yang diuji & 6.651 & 6.188 \\
\hline
\end{tabular}

Sumber: Dinas Perhubungan UPTD PKB Kota Sukabumi Tahun 2018-2019

Data pada Tabel 1 menggambarkan bahwa jumlah kendaraan yang diuji mengalami penurunan setiap tahunnya. Pada tahun 2018, jumlah kendaraan yang diuji sebesar 6.651 kendaraan, sedangkan pada tahun 2019 jumlah kendaraan yang diuji sebesar 6.188 kendaraan. Hal tersebut disebabkan masih banyak pemilik kendaraan yang tidak melakukan proses pengujian kendaraan bermotor. Masih terdapat kurangnya kesadaran masyarakat akan pentingnya pengujian kendaraan bermotor guna memberikan keselamatan secara teknis terhadap penggunaan kendaraan bermotor.

Berdasarkan hasil observasi awal, peneliti menemukan sejumlah fenomena masalah sebagai berikut:

1. Pendapatan Asli Daerah (PAD) melalui pengujian kendaraan bermotor mengalami peningkatan bahkan melampui target yang telah ditentukan sebesar 20\%. Salah satu peningkatan Pendapatan Asli Daerah tersebut didapatkan dari indikator pelaksanaan teknis pengujian kendaraan bermotor yang meliputi uji pertama masuk, pengujian berkala, kehilangan buku uji, denda periode, dan penilaian kondisi teknis.

2. Pencapaian Pendapatan Asli Daerah terbanyak salah satunya ada pada pelaksanaan teknis, yaitu kehilangan buku uji dan denda periode. Hal ini disebabkan oleh kurangnya kesadaran dan kedisiplinan pemilik kendaraan terhadap pentingnya buku uji. Peraturan Walikota Nomor 1 Tahun 2018 tentang Tarif Retribusi Pengujian Kendaraan Bermotor mengatur pengenaan biaya sebesar Rp 250.000 bagi pemilik kendaraan yang menghilangkan atau merusak buku uji pada saat melakukan proses pengujian kendaraan bermotor dan kendaraan yang mengalami keterlambatan jatuh tempo habis masa uji dikenakan denda sebesar Rp 50.000/periode (maksimal 4 periode). Hal ini menjadi salah satu penyebab meningkatnya Pendapatan Asli Daerah Kota sukabumi.

3. Sosialisasi telah dilaksanakan oleh Dinas Perhubungan Kota Sukabumi, akan tetapi pelaksanaannya belum 
maksimal. Data yang peneliti peroleh menunjukkan bahwa masih banyak kendaraan yang tidak melakukan proses pengujian kendaraan bermotor.

Berdasarkan latar belakang tersebut, peneliti tertarik untuk mengetahui implementasi strategi pengujian kendaraan bermotor oleh UPTD PKB Dinas Perhubungan Kota Sukabumi.

\section{MATERI DAN METODE}

\section{Konsep/Teori yang Relevan}

Sabariah (2016: 21) menyatakan bahwa strategi merupakan submanajemen dari organisasi dimana strategi merupakan ilmu teori dan seni yang beragam dari perusahaan yang berbeda dalam pembuatan perumusan pada saat pertanyaan "apa yang harus dilakukan", muncul dalam pemikiran pembuat rencana (konseptor strategis), dan kemudian penerapan, terjadi saat berfikir "bagaimana mengerjakannya" sebagaimana tentunya, berkaitan dengan tindakan yang terkait dengan pemikiran yang menarik dan intuisi saja, dan terakhir adalah melakukan evaluasi (evaluating), antar fungsi-fungsi yang memungkinkan sebuah organisasi mencapai tujuan.

Berdasarkan pengertian di atas dapat diartikan bahwa strategi adalah suatu upaya atau rencana yang dilakukan sebuah organisasi/lembaga pemerintahan untuk mencapai suatu tujuan yang telah ditetapkan dan diinginkan. Strategi dalam perumusan rencana diawali dengan analisis SWOT (strength/kekuatan, weakness/ kelemahan, opportunity/peluang, threat/ ancaman) dengan harapan dapat mengembangkan misi yang dijabarkan ke dalam tujuan dalam jangka panjang dan jangka pendek, kemudian dalam penerapan dan implementasi strategi seperti tindakan nyata dari penjabaran tersebut. Melakukan evaluasi strategi dapat ditempuh melalui penilaian hasil keseluruhan yang dibandingkan dengan data dari berbagai sumber. Jika terjadi ketidaksesuaian, dilakukan perbaikan. Strategi dibangun oleh setiap fungsi dimana setiap fungsi harus mencapai tujuan masing-masing.

Dess dan Miller (Winardi, 2003: 113114) mengemukakan tiga dimensi strategi dalam melaksanakan kebijakan dan rencana untuk mencapai tujuan/sasaran organisasi.

1. Sasaran (Goal). Tujuan-tujuan atau sasaran-sasaran yang paling penting dan yang perlu dicapai. Tujuan-tujuan atau sasaran-sasaran menyatakan apa saja yang perlu dicapai, kapan hasilhasil harus dilaksanakan dari sasaransasaran nilai, menyatakan kearah mana organisasi tersebut menuju, melalui berbagai macam sasaran keorganisasian yang bersifat menyeluruh, yang menetapkan sifat organisasi, dan menetapkan target bagi setiap kesatuan keorganisasiannya.

2. Kebijakan (Policy). Kebijakan-kebijakan paling penting dan mengarahkan atau membatasi kegiatan-kegiatan. Kebijakan-kebijakan merupakan peraturanperaturan atau prosedur-prosedur yang menggariskan batas-batas dimana kegiatan akan dilaksanakan. Peraturanperaturan demikian seringkali mencapai keputusan-keputusan kontigen guna menyelesaikan konflik antara sasaran-sasaran spesifik. Tahapantahapan tindakan pokok atau programprogram yang akan mencapai tujuantujuan yang ditetapkan dalam batasbatas yang telah digariskan. Programprogram menspesifikasi langkah demi langkah tahapan-tahapan tindakan yang diperlukan untuk mencapai sasaran-sasaran utama. Program dan tindakan menyatakan bagaimana sasaran-sasaran akan tercapai di dalam batas-batas oleh kebijakan. Di samping itu, sumber-sumber daya diarahkan ke arah pencapaian tujuan dan dengan apa kemajuan organisasi dapat diukur.

3. Rencana (Plan). Strategi adalah suatu rencana yang mempunyai tujuan yang akan dicapai oleh suatu organisasi, adanya kebijakan agar memudahkan 
menetapkan suatu arah yang akan dicapai oleh sebuah organisasi dan rencana yang mengatur sebuah tindakan agar strategi yang disusun lebih efektif dan efisien dalam pencapaian tujuannya. Strategi sebuah perencanaan dan manajemen berfungsi menunjukkan arah dan taktik operasional perencanaan untuk dilaksanakan oleh pimpinan organisasi dalam mencapai tujuan organisasi yang telah ditetapkan.

\section{Metode}

Penelitian ini dilaksanakan pada Dinas Perhubungan Kota Sukabumi, dalam hal ini UPTD PKB. Fokus penelitian ditujukan untuk mengetahui implementasi strategi pengujian kendaraan bermotor oleh UPTD PKB Dinas Perhubungan Kota Sukabumi. Implementasi strategi dimaksud didefinisikan secara operasional sebagai pelaksanaan kebijakan dan rencana Dinas Perhubungan Kota Sukabumi untuk mencapai sasaran/ tujuan yang telah ditetapkan, yaitu (1) meningkatnya kendaraan yang laik jalan dan (2) meningkatnya pungutan retribusi guna berkontribusi terhadap Pendapatan Asli Daerah). Implementasi strategi tersebut diukur berdasarkan tiga dimensi, yaitu sasaran, kebijakan dan rencana.

Metode penelitian yang digunakan adalah metode kualitatif. Data dikumpulkan melalui wawancara, observasi dan dokumentasi. Penentuan informan dalam penelitian ini menggunakan nonprobability sampling yaitu dengan menggunakan metode purposive sampling. Dalam penelitian kualitatif, penarikan sampel didasarkan pada tujuan. Karena tujuan objek penelitian kualitatif yang akan diteliti sudah dipastikan, maka menjadi pertimbangan yang sesuai situasi maupun fokus penelitian, penelitian memilih subjek atau objek sebagai unit analisis. Untuk mendapatkan data yang diperlukan dan dibutuhkan subjek penelitian ini menjadi informan yang akan memberikan berbagai informasi yang diperlukan selama proses penelitian melalui wawancara. Adapun informan yang ditentukan secara purposif ditunjukkan pada Tabel 2 .

Tabel 2. Informan Penelitian

\begin{tabular}{|c|c|c|}
\hline Informan & Jabatan & Alasan \\
\hline \multirow{5}{*}{$\begin{array}{l}\text { Informan } \\
1\end{array}$} & Kepala & Kepala yang memimpin \\
\hline & UPTD PKB & UPTD PKB dalam \\
\hline & & Menyelenggarakan \\
\hline & & Pengujian Kendaraan \\
\hline & & Bermotor \\
\hline \multirow{5}{*}{$\begin{array}{l}\text { Informan } \\
2\end{array}$} & Kasubag & Kepala yang Membantu \\
\hline & TU UPTD & Kepala UPTD PKB \\
\hline & PKB & dalam Melaksanakan \\
\hline & & Pengujian \\
\hline & & Kendaraan Bermotor \\
\hline \multirow{2}{*}{$\begin{array}{l}\text { Informan } \\
3\end{array}$} & Pelaksa & Pegawai yang Melaksa- \\
\hline & Seksi & $\begin{array}{l}\text { nakan Pengujian Ken- } \\
\text { daraan Bermotor }\end{array}$ \\
\hline \multirow{5}{*}{$\begin{array}{l}\text { Informan } \\
4\end{array}$} & Pemohon & Pemohon yang Melak- \\
\hline & Peserta & Pengujian \\
\hline & Pengujian & Kendaraan Bermotor \\
\hline & Kendaraan & \\
\hline & Bermotor & \\
\hline \multirow{3}{*}{$\begin{array}{l}\text { Informan } \\
5\end{array}$} & Sopir & Sopir yang Melaksana- \\
\hline & Angkutan & kan Pengujian Kenda- \\
\hline & Kota & raan Bermotor \\
\hline
\end{tabular}

Sumber: Penelitian 2020

Data penelitian yang telah dikumpulkan dianalisis secara kualitatif dengan menggunakan model analisis interaktif Milles dan Hubberman yaitu pengumpulan data, reduksi data, penyajian data dan penarikan kesimpulan (Patilima, 2007; Satori dan Komariah, 2011; Sugiyono, 2016, 2017).

\section{HASIL DAN PEMBAHASAN}

Hasil dan pembahasan tentang implementasi strategi pengujian kendaraan bermotor oleh UPTD PKB Dinas Perhubungan Kota Sukabumi dilakukan berdasarkan tiga dimensi sebagai berikut:

\section{Dimensi Sasaran (Goal)}

Strategi di dalamnya mencakup sasaran. Sasaran dalam penelitian ini dilihat dari bagaimana sasaran yang dilakukan dalam pengujian kendaraan bermotor. Untuk melihat sasaran yang dilakukan tersebut, peneliti mencari informasi kepada informan 
yang terlibat dalam pengujian kendaraan bermotor di Kota Sukabumi. Terkait hal ini, pertanyaan yang diajukan adalah: Siapa yang menjadi sasaran dari pengujian kendaraan bermotor? Apa tujuan dari pengujian kendaraan bermotor tersebut?

Jawaban informan menyatakan bahwa sasaran dari pengujian kendaraan bermotor adalah pengusaha yang memiliki kendaraan angkutan barang/angkutan orang, khususnya kendaraan yang berdomisili di wilayah Kota Sukabumi dan kepada instansi pemerintah yang memiliki wajib uji serta tujuan dari pengujian kendaraan bermotor tersebut adalah untuk memberikan keselamatan di jalan dan melestarikan lingkungan agar tidak terjadinya pencemaran lingkungan. Informan juga menyatakan hal yang sama mengenai sasaran dari proses pengujian kendaraan bermotor adalah masyarakat yang memiliki kendaraan angkutan barang/angkutan umum di wilayah Kota Sukabumi dan kepada instansi yang memiliki kendaraan wajib uji serta tujuan dan manfaat dari pengujian kendaraan bermotor sebagaimana diatur dalam Peraturan Daerah Nomor 4 Tahun 2004 tentang Pengujian Kendaraan Bermotor. Adapun proses pengujian kendaraan bermotor di Kota Sukabumi ditunjukkan pada Gambar 1.

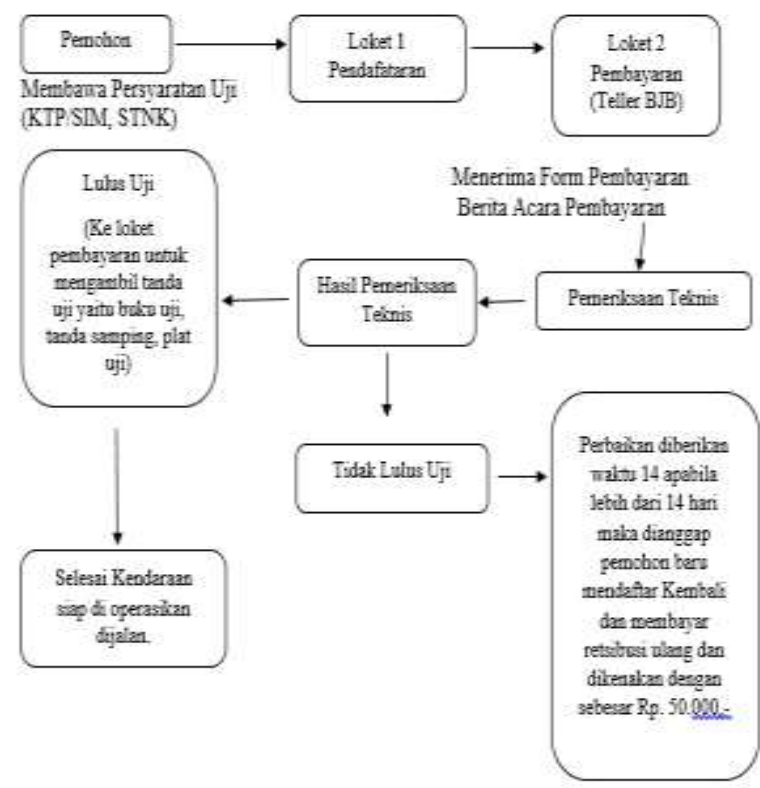

Gambar 1. Proses Pengujian Kendaraan Bermotor
Setelah dilakukan pemeriksaan teknis dan diperoleh hasil bahwa kendaraan dinyatakan tidak lulus uji terdapat kekurangan/kerusakan yang harus diperbaiki misalnya lampu rem yang mati, ban gundul, mengubah spek kendaraan seperti dimodifikasi menjadi ceper (pendek), rem dan kondisi shockbreaker tidak normal. Gambar 2 menunjukkan contoh kendaraan yang tidak lulus uji karena terdapat kekurangan seperti ban gundul dan rem tidak normal.

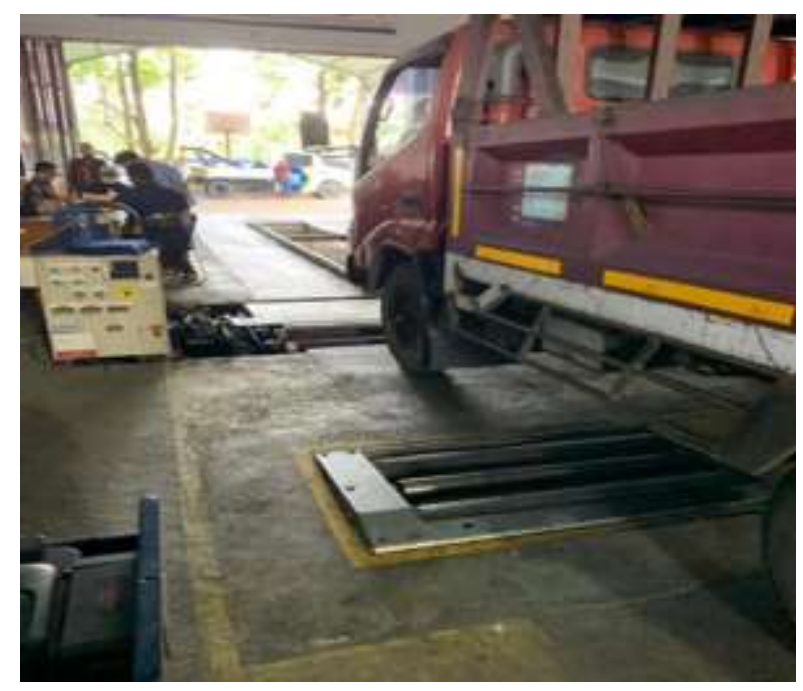

Gambar 2. Kendaraan Tidak Lulus Uji

Gambar 2 menggambarkan kendaraan yang tidak lulus uji karena masih terdapat kekurangan atau kerusakan pada kendaraan tersebut dan harus diperbaiki. Pada saat kendaraan dinyatakan tidak lulus uji, kepada pemilik atau pemegang kendaran diberikan waktu paling lama 14 hari sejak diterbitkannya surat keterangan tidak lulus uji dan kepada pemohon tidak diperlakukan sebagai pemohon baru, serta tidak dipungut biaya uji. Apabila waktu yang diberikan selama 14 hari tersebut melebihi batas waktu yang telah ditetapkan, kepada pemohon melakukan pendaftaran ulang proses pengujian kendaraan bermotor dan biaya uji pun kembali ke awal dan jika kendaraan yang melebihi batas waktu yang diberikan dikenakan denda periode sebesar $\mathrm{Rp}$ 50.000 peraturan tersebut terdapat pada Peraturan Wali Kota Nomor 1 Tahun 2018 tentang Tarif Retribusi Pengujian Kenda- 
raan Bermotor. Adapun data jumlah pemilik kendaraan yang dikenakan denda atau kendaraan yang melewati jatuh tempo ditunjukkan pada Tabel 3.

Tabel 3. Data Jumlah Pemilik Kendaraan yang denda periode atau jatuh tempo Tahun 2018-2019

\begin{tabular}{lcc}
\hline \multirow{2}{*}{ Tahun } & \multicolumn{2}{c}{ Jumlah Pemohon } \\
\cline { 2 - 3 } & $\begin{array}{c}\text { Denda Periode/ } \\
\text { Jatuh Tempo }\end{array}$ & $\begin{array}{c}\text { Jumlah } \\
\text { Pendapatan }\end{array}$ \\
\hline 2018 & 2.082 & 104.125 .000 \\
\hline 2019 & 3.006 & 150.300 .000 \\
\hline
\end{tabular}

Sumber: Dinas Perhubungan UPTD PKB Kota Sukabumi Tahun 2018-2019

Tabel 3 menunjukkan bahwa setiap tahunnya pemilik kendaraan yang mengalami denda periode atau jatuh tempo meningkat sebesar 50\%. Berdasarkan hasil observasi yang dilakukan oleh peneliti, yang menjadikan penyebab meningkatnya denda periode adalah kurangnya kesadaran masyarakat seperti masih ditemukan pemohon yang lupa akan kendaraan yang sudah melebihi batas waktu yang diberikan. Kendaraan yang mengalami rusak berat dan waktu yang diperlukan untuk perbaikan kendaraan tersebut membutuhkan waktu yang cukup lama sehingga mengakibatkan pengulangan prosedur pengujian kendaraan bermotor dan dikenakan denda periode tersebut. Gambar 3 menunjukkan data kendaraan yang diuji di wilayah Kota Sukabumi.

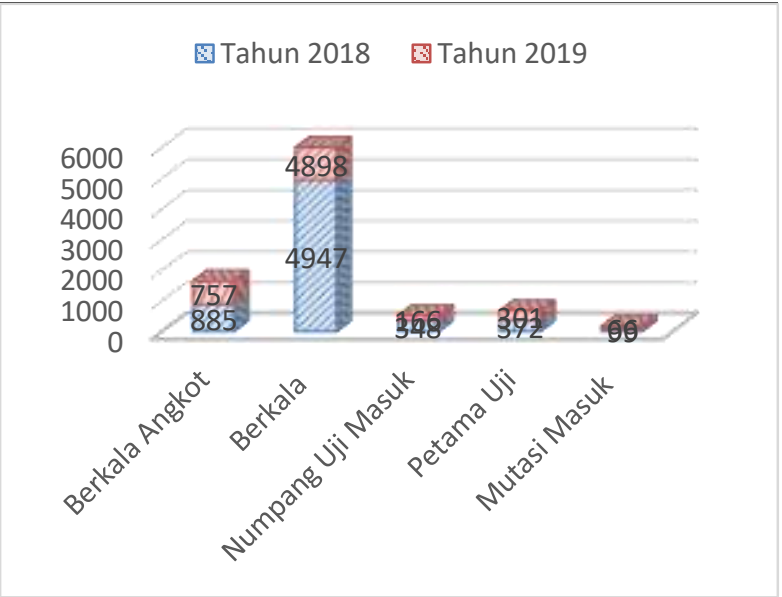

Sumber: Dinas Perhubungan UPTD PKB Kota Sukabumi Tahun 2018-2019

Gambar 3. Data Jumlah Kendaraan yang Diuji UPTD PKB Kota Sukabumi Tahun 2018-2019
Selanjutnya peneliti mencari informasi kembali dengan pertanyaan yang sama kepada infoman di waktu yang berbeda. Jawaban dari informan masih senada dengan jawaban dari informan lainnya yang mengikuti prosedur pengujian kendaraan bermotor, namun tidak mengetahui tujuan dari pengujian kendaraan bermotor itu sendiri.

Dari jawaban informan, sasaran dalam pengujian kendaraan bermotor adalah kepada seluruh masyarakat yang memiliki kendaraan wajib uji, khususnya wilayah Kota Sukabumi. Pernyataan tujuan pengujian kendaraan bermotor pada informan terdapat persamaan, yaitu agar kendaraan bermotor memberikan jaminan keselamatan secara teknis terhadap penggunaan kendaraan bermotor, mendukung kelestrarian lingkungan dari pencemaran udara, memberikan pelayanan umum kepada masyakarat. Dari wawancara yang peneliti lakukan masih terdapat informan yang tidak mengetahui tujuan dari pengujian kendaraan bermotor. Hal ini dapat ditafsirkan sebagai fakta yang membuktikan masih adanya masyarakat yang belum mengetahui tujuan dari pengujian kendaraan bermotor.

Pernyataan informan juga sejalan dengan hasil observasi yang dilakukan oleh peneliti, yakni masih ada kendaraan yang melebihi muatan dan asap hitam yang keluar dari pembuangan gas emisi kendaraan tersebut. Gambar 4 secara faktual menunjukkan masih adanya kendaraan yang bermuatan melebihi kapasitas yang dapat menyebab-kan kecelakaan lalu lintas dan kendaraan yang berasap tebal dapat menyebabkan pencemaran lingkungan dan polusi udara. Dari hasil observasi dan wawancara yang peneliti lakukan dapat diinterprestasikan bahwa masih terdapat masyarakat yang belum mengetahui tujuan dari pengujian kendaraan bermotor dan masih terdapat kendaraan yang melebihi muatan dan asap hitam yang keluar dari pembuangan gas emisi kendaraan. 


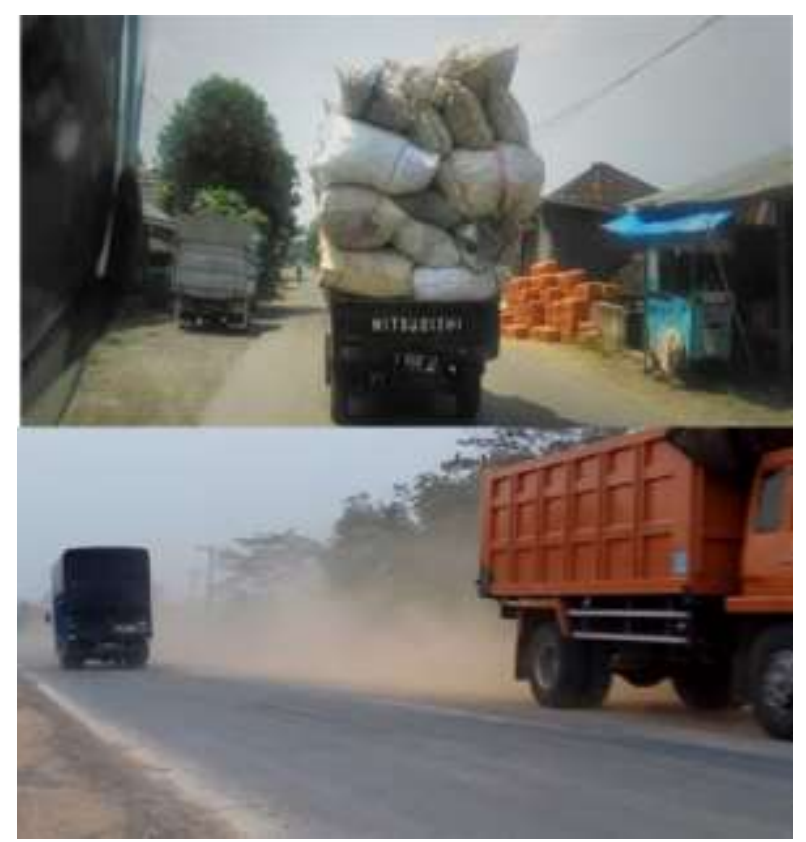

Gambar 4. Kendaraan Melebihi Muatan dan Berasap Tebal

Realitas bahwa masih terdapat kendaraan yang melebihi muatan dan asap hitam yang keluar dari pembuangan gas emisi kendaraan sebagaimana dibuktikan pada Gambar 4 tidak sesuai dengan Peraturan Daerah Nomor 4 Tahun 2004 tentang Pengujian Kendaraan Bermotor. Pasal 1 ayat 22 mengatur bahwa laik jalan adalah persyaratan minimum kondisi suatu kendaraan bermotor yang harus dipenuhi agar terjamin keselamatan dan mencegah terjadinya pencemaran udara dan kebisingan lingkungan pada waktu dioperasikan di jalan. Tujuan atau sasaran sangat penting untuk menunjang keberhasilan organisasi. Namun, dalam hal ini sasaran dari pengujian kendaraan bermotor belum memahami tujuan maupun manfaat dari pengujian kendaraan bermotor. Hal ini tentunya dapat menghambat keberhasilan implementasi pengujian kendaraan bermotor.

\section{Dimensi Kebijakan (Policy)}

Kebijakan dapat diartikan sebagai rangkaian keputusan dan membatasi tindakan yang dilakukan adanya kebijakan agar memudahkan menetapkan suatu arah yang akan dicapai oleh organisasi. Terkait hal ini, pertanyaan yang diajukan oleh peneliti kepada informan adalah: Apa kebijakan yang dilakukan dalam rangka pembentukan kesadaran masyarakat terkait pengujian kendaraan bermotor?

Dari aspek kebijakan, pembentukan kesadaran masyarakat dalam kaitan dengan pengujian kendaraan bermotor pada dasarnya mengacu pada Undang-Undang Nomor 22 Tahun 2009 tentang Lalu Lintas dan Angkutan Jalan, yaitu mengedukasi tentang keselamatan berlalu lintas. Sementara itu, pelaksanaan teknis akan pentingnya pengujian kendaraan bermotor terdapat pada Pasal 48 Ayat 1 yang menyatakan bahwa setiap kendaraan bermotor yang dioperasikan di jalan harus memenuhi persyaratan teknis dan laik jalan.

Dinas Perhubungan Kota Sukabumi, dalam hal ini UPTD PKB, telah berupaya untuk membentuk kesadaran masyarakat melalui kebijakan yang terdapat pada Peraturan Daerah Nomor 15 Tahun 2011 tentang Retribusi Pengujian Kendaraan Bermotor. Pasal 23 huruf (b) angka 3, 4, 5 dan 6 yang mengatur bahwa tarif buku uji, penggantian buku uji yang rusak atau hilang dikenakan tarif sebesar Rp 15.000 telah direvisi menjadi Peraturan Walikota Nomor 1 Tahun 2018 tentang Tarif Retribusi Pengujian Kendaraan Bermotor yang mengatur bahwa bagi pemilik kendaraan yang menghilangkan buku uji dikenakan tarif sebesar Rp 250.000.

Adanya perubahan tarif buku uji pengujian kendaraan bermotor tersebut dimaksudkan untuk menekan pelanggaran kepada pemilik kendaraan yang sengaja menghilangkan buku uji, dengan cara menaikkan tarif denda menjadi Rp 250.000. Diberlakukannya perubahan tersebut dapat memberikan efek jera kepada pemilik kendaraan agar lebih tertib menyimpan dan menjaga buku uji karena dokumen tersebut adalah dokumen negara yang penting dan bukti kendaraan tersebut layak beroperasi di jalan.

Data menunjukkan bahwa pemilik kendaraan yang menghilangkan buku uji 
setiap tahun mengalami peningkatan hingga 50\%. Hal ini tidak sedikit yang terkesan mengabaikan buku uji kendaraan, terutama pemilik kendaraan angkutan umum, sehingga buku uji atau tanda lulus kendaraan sering hilang. Kebijakan yang dilakukan dalam rangka pembentukan kesadaran masyarakat mengacu pada dasar hukum sebagaimana diatur dalam Peraturan Walikota Nomor 1 Tahun 2019 tentang Tarif Retribusi Pengujian Kendaraan Bermotor.

Khusus berkaitan dengan kendaraan angkutan umum perkotaan (angkot), Pemerintah Kota Sukabumi melalui Dinas Perhubungan, memberlakukan kebijakan penghapusan tarif retribusi bagi pemilik kendaraan angkutan umum perkotaan (angkot) yang melakukan proses pengujian kendaraan bermotor. Tujuan pemberlakuan penghapusan tarif retribusi tersebut adalah agar pemilik kendaraan angkutan umum perkotaan mau melakukan pengujian kendaraan bermotor. Hal ini adalah bentuk kepedulian Pemerintah Kota Sukabumi untuk meringankan beban pengemudi dan pengusaha angkutan umum. Akan tetapi berdasarkan hasil observasi yang peneliti temukan dan dengan data yang peneliti peroleh masih banyak kendaraan angkutan umum perkotaan yang belum patuh untuk melakukan pengujian kendaraan bermotor. Salah satu sebabnya adalah pemilik kendaraan angkutan umum perkotaan yang masih belum mengetahui adanya kebijakan perubahan tarif retribusi pengujian kendaraan bermotor tersebut. Hal ini sejalan dengan hasil observasi yang peneliti lakukan dan dengan data yang peneliti peroleh bahwa sosialisasi yang dilakukan Dinas Perhubungan Kota Sukabumi, dalam hal ini UPTD PKB, belum maksimal. Sosialisasi yang dilakukan hanya melalui media berupa layanan laman (website) Dinas Perhubungan dan radio siaran Pemerintah Daerah.

Kebijakan penghapusan tarif retribusi bagi para pemilik kendaraan angkutan umum perkotaan (angkot) dibuat untuk meringankan pemilik angkutan umum dan untuk melestarikan lingkungan dari polusipolusi yang timbul dari asap hitam angkutan umum, namun masih banyak kendaraan angkutan umum yang belum patuh untuk melakukan pengujian kendaraan bermotor. Kebijakan tersebut perlu disosialisasikan secara intensif baik secara langsung maupun melalui media konvensional dan alternatif agar terbentuk kesadaran masyarakat dalam pengujian kendaraan bermotor.

\section{Dimensi Rencana (Plan)}

Strategi yang diterapkan dapat terlaksana dengan maksimal dibutuhkan rencana untuk mengatur tindakan yang dilakukan. Terkait hal ini, pertanyaan yang diajukan oleh peneliti kepada informan adalah: Apa rencana yang dibuat dalam rangka pembentukan kesadaran masyarakat terkait pengujian kendaraan bermotor?

Dari pernyataan informan penelitian, rencana yang telah dibuat untuk pembentukan kesadaraan masyarakat adalah dengan mengintroduksi inovasi yang dinamakan Panon Pendekar (Pembayaran NonTunai Pengujian Kendaraan Bermotor). Inovasi ini sudah ada sejak September 2019. Inovasi ini dimaksudkan untuk memudahkan masyarakat dalam melakukan proses pengujian kendaraan bermotor, khususnya dalam melakukan pembayaran tanpa harus membawa uang tunai ke loket pembayaran. Pelayanan sistem pembayaran nontunai dilakukan dari satu perangkat EDC (Electronic Data Capture) yang tersedia sebagai alat pembayaran retribusi dengan cara menggesekan kartu ATM kredit atau debit. Kartu tersebut harus mengisi PIN dan pembayaran langsung diterima oleh Bank BJB.

Kepada informan penelitian juga diajukan pertanyaan berikut: Bagaimana hadirnya inovasi Panon Pendekar (sistem pembayaran non tunai)? Bagaimana sosialisasi dilakukan terkait inovasi tersebut? Dari jawaban informan penelitian, sosialisasi yang dilakukan masih kurang maksimal, disebabkan masih adanya pemilik 
kendaraan yang tidak mempunyai kartu anjungan tunai mandiri. Inovasi yang telah dibuat ini pun dimaksudkan untuk meminimalisir pungutan liar yang dilakukan oleh oknum petugas, lebih aman dalam transaksi pembayaran, transparansi dalam pelaporan keuangan, dan sekaligus biaya pengujian kendaraan bermotor.

Akan tetapi realitas di lapangan masih ditemukan adanya masyarakat atau pemohon yang sebagian belum memiliki kartu anjungan tunai mandiri. Pihak yang datang ke tempat pengujian kendaraan bermotor biasanya bukan pemilik kendaraan, tetapi dilakukan oleh orang lain yang bukan pemilik kendaraan, sedangkan pemilik kendaraan tidak memberikan kartu anjungan tunai mandiri untuk melakukan pembayaran. Ada sebagian pemohon yang tidak membawa kartu anjungan tunai mandiri tetapi membawa uang tunai. Kerumitan yang ditemukan terjadinya pemohon belum mengetahui inovasi sistem pembayaran nontunai pengujian kendaraan bermotor melalui Panon Pendekar. Berdasarkan hal tersebut dapat diketahui bahwa rencana yang dilakukan terkait inovasi Panon Pendekar yang manfaatnya adalah untuk mempermudah masyarakat dalam melakukan pembayaran belum terlaksana dengan baik. Rencana yang ada pada program pengujian kendaraam bermotor ini harus terpadu, dalam hal ini semua stakeholder harus siap dan memahami dari rencana yang telah dicanangkan. Agar rencana tersebut dapat berjalan sebagaimana mestinya.

\section{KESIMPULAN DAN REKOMENDASI}

\section{Kesimpulan}

Berdasarkan hasil penelitian yang telah dianalisis mengenai implementasi strategi pengujian kendaraan bermotor oleh UPTD PKB Dinas Perhubungan Kota Sukabumi, maka dapat disimpulkan sebagai berikut:

1. Sasaran dalam pengujian kendaraan bermotor secara umum sudah dikata- kan cukup baik, namun masih terdapat hambatan, yaitu sebagian besar pemilik kendaraan tidak mengetahui manfaat dan tujuan dalam melaksanakan pengujian kendaraan bermotor.

2. Kebijakan terkait pengujian kendaraan bermotor belum disosialisasikan secara massif dan masih lemahnya pengawasan kepada pemilik kendaraan yang menghilangkan buku uji.

3. Rencana yang sudah dibuat untuk meningkatkan kesadaran masyarakat melalui inovasi pembayaran retribusi secara nontunai masih terhambat pada kurangnya kesadaran masyarakat. Dengan adanya inovasi tersebut masih terdapat pemilik kendaraan yang sebagian besar belum memiliki Kartu ATM BJB karena belum mengetahui inovasi sistem pembayaran nontunai pengujian kendaraan bermotor.

\section{Rekomendasi}

Berdasarkan kesimpulan tersebut, maka direkomendasikan upaya-upaya sebagai berikut:

1. Diharapkan adanya kerjasama yang baik antara masyarakat dan UPTD PKB Dinas Perhubungan Kota Sukabumi dengan selalu melengkapi surat-surat kendaraan bermotor dan taat melakukan pengujian terhadap setiap kendaraan yang dimiliki karena kendaraan yang tidak layak pakai jika beroperasi maka akan berisiko pada kecelakaan yang dapat merugikan orang lain dan diri sendiri.

2. Diperlukan sosialisasi dan penyuluhan secara massif oleh UPTD PKB Dinas Perhubungan Kota Sukabumi tentang pengujian kendaraan bermotor sehingga timbul kesadaran masyarakat akan pentingnya pengujian kendaraan bermotor yang berdampak pada berkurangnya kendaraan yang tidak layak uji.

3. Disarankan adanya pengembangan sistem layanan pembayaran nontunai 
tidak hanya melalui Bank BJB, tetapi juga bekerja sama dengan bank-bank lain untuk lebih mempermudah layanan sistem pembayaran nontunai.

\section{DAFTAR PUSTAKA}

\section{Buku}

Agung, Julianto. (2003). Manajemen Strategis. Yogyakarta: Andi.

Bungin, Burhan. (2007). Penelitian Kualitatif: Komunikasi, Ekonomi, Kebijakan Publik dan Ilmu Sosial lainnya. Jakarta: Putra Grafika.

Darise. (2009). Pengelolaan Keuangan Daerah. Jakarta: Penerbit PT. Indeks.

Heene, Aime dan Sebastian Desmidt. (2010). Manajemen Strategik Keorganisasian Publik. Bandung: PT Refika Aditama.

Nawawi, Hadari. (2004). Manajemen Strategik: Organisasi Non-Profit Bidang Pemerintahan. Yogyakarta: Gadjah Mada University Press.

Patilima, Hamid. (2007). Metode Penelitian Kualitatif. Bandung: Alfabeta.

Sabariah. (2016). Manajemen Strategis. Jakarta: Pustaka Pelajar.

Saladin, Djasalim. (2003). Manajemen Strategi \& Kebijakan Perusahaan. Bandung: Linda Karya.

Satori dan Komariah. (2011). Metode Penelitian Kualitatif. Bandung: Alfabeta.

Siagian, Sondang P. (2018). Manajemen Strategik. Jakarta: Bumi Aksara.

Sugiyono. (2016). Metode Penelitian Kualitatif dan R\&B. Bandung: Alfabeta.

Sugiyono. (2017). Metode Penelitian Kualitatif. Kuantitatif dan $R \& D$. Bandung: Alfabeta.

Winardi, J. (2003). Entrepeuner \& Entrepreneurship. Jakarta: Prenada Media.

\section{Jurnal}

Anisa, Imelia. (2016). "Penerimaan Retribusi Pengujian Kendaraan Bermotor
Dalam Menunjang Pendapatan Asli Daerah (PAD) di UPTD Pengujian Kendaraan Bermotor Dinas Perhubungan Kota Samarinda". e-Jurnal Administrasi Negara, 4(3): 4611-4621. http://ejournal.ap.fisip-unmul.ac.id/ site/wp-content/uploads/2016/08/ Jurnal\%20FIX\%20IMEL\%20(08-2516-02-49-38).pdf.

\section{Skripsi}

Alim, Rohman Nur. (2019). Evaluasi Pendapatan Asli Daerah Pengujian Kendaraan Bermotor pada Dinas Perhubungan Kota Bandung Tahun Anggaran 2013-2017. Bandung: UIN Sunan Gunung Djati. http://digilib. uinsgd.ac.id/id/eprint/21820.

Sari, Nopiyah. (2016). Analisis Optimalisasi Penerimaan Retribusi Pengujian Kendaraan Bermotor pada Dinas Perhubungan Kota Palembang. Palembang: Universitas Muhammadiyah Palembang. http://repository.umpalembang.ac.id/id/eprint/1599/.

Syahputra, Ade Reza. (2015). Efektivitas Pelayanan Pengujian Kendaraan Bermotor Dalam Rangka Meningkatkan Pendapatan Asli Daerah pada Dinas Perhubungan Kota Bandar Lampung. Bandar Lampung: Jurusan Ilmu Administrasi Negara Fakultas Ilmu Sosial dan Ilmu Politik Universitas Lampung. https://123 dok.com/document/oz13rm3qefektivitas-pelayanan-pengujiankendaraan-bermotor-meningkatkanpendapatan-perhubungan.html.

Zulfauziah, Jinang. (2018). Kinerja Dinas Perhubungan dalam Pelayanan Pengujian Kendaraan Bermotor Jenis Angkutan Barang di Kabupaten Pinrang. Makassar: Program Studi Administrasi Negara Departemen Ilmu Administrasi Fakultas Ilmu Sosial dan Ilmu Politik Universitas Hasanuddin. http://digilib.unhas.ac.id/ uploaded_files/temporary/DigitalColl ection/Zjg3ODYxN2MzNGFjNmJlNGNl 
OTVjY2RiOGE2MDA2NWQyZmZiM2I

$w M w==. p d f$.

\section{Peraturan Perundang-undangan}

Peraturan Daerah Kota Sukabumi Nomor 4 Tahun 2001 tentang Pengujian Kendaraan Bermotor (Lembaran Daerah Kota Sukabumi Tahun 2001 Nomor 4 Seri B-1).

Peraturan Walikota Nomor 1 Tahun 2018 tentang Tarif Retribusi Pengujian Kendaraan Bermotor (Berita Daerah Kota Sukabumi Tahun 2018 Nomor 1).

Undang-Undang Republik Indonesia Nomor 33 Tahun 2004 tentang Perimbangan Keuangan antara Pemerintah Pusat dan Pemerintahan Daerah (Lembaran Negara Republik Indonesia Tahun 2004 Nomor 126, Tambahan Lembaran Negara Republik Indonesia Nomor 4438). 